\title{
Effect of Foliar Application some Plant Growth Regulators on Growth and Productivity of Olive Trees under South Egypt Conditions Abo- El-Ez, A. E. T. ${ }^{1}$; Shereen A. Shaheen ${ }^{2}$ and Hadeer M. Abo-Eloun ${ }^{2}$ ${ }^{1}$ Faculty of agriculture, Sohag University. ${ }^{2}$ Horticulture Research Institute, Giza, Egypt.
}

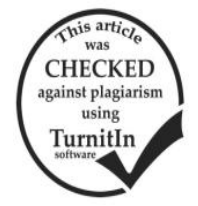

\begin{abstract}
This study was carried out through three successive seasons 2014, 2015 and 2016 to study the effect of Salicylic acid at (200 \&400 $\mathrm{ppm})$ and Naphthalene acetic acid at (50\& $100 \mathrm{ppm})$ as a foliar application on flowering, fruiting, yield and fruit quality of Picual and Manzanillo cvs olive trees (9 years old). Planted 6x6 apart at Horticultural Station Orchard at Shandaweel region, Sohag Governorate. The results indicated that foliar spray of salicylic acid at $200 \mathrm{ppm}$ is recommended for improving productivity attributed to increase flowering percentage and density, as well as percentage of sex expression. Moreover, treatments reduced the alternative bearing and enhanced the fruit physical properties. Furthermore, each of two Salicylic acid concentration ( $200 \& 400$ ppm) improved fruit oil content.
\end{abstract}

Keywords: Salicylic acid, Naphthalene acetic acid, foliar application, Olive cultivars "Picual", "Manzanillo".

\section{INTRODUCTION}

Olive (Olea europaea L.) is a long-lived evergreen tree belongs to family Oleaceae, one of the oldest cultivated trees that known in the history of the world about 8000 years ago. Olive tree is mentioned in several verses of the Quran and holy books.

It is widely cultivated and economically important fruit crop for several countries, in many arid zones of the world, native to all the countries around the Mediterranean that presents of about $90 \%$ of the world's olive cultivation and production. Olive fruits can be consumed either fully ripe black or as the unripe green for pickling or oil extracting. Picual and Manzanillo cvs. are considered of the most important commercial olive cultivars which cultivated in Egypt and can be used for pickling, oil extraction or for the double purposes. However, productivity of olive trees is affected by some environmental factors, whereas, the trees must be exposed to a period of winter chilling temperatures (vernalization) in some countries that located under warm winter conditions such as Egypt in order to emerge the inflorescences in the spring. Considerable interests have been shown on other plants by using some materials that can make the same action such as antioxidants especially salicylic acid (Mahdi et al., 2012).

Salicylic acid (SA) is a phenolic compound also known as (Ortho-hydroxybenzoic acid), it considered a natural constituent of plant, which are safe to human and environment and plays an important role as an endogenous regulators. Also consider as thermo genesis in plant for achieving the vernalization (Raskin, 1992 and Reda et al., 2010). Moreover, protecting the cells from senescence and preventing free radicals from oxidation of lipids the components of plasma membrane. (Ahmed et al., 2014, Abada and Abd El-Hameed, 2010 and Wassel et al., 2011). Salicylic acid is responsible for enhancing natural hormones that play a key part in regulating plant growth and development which enhanced the yield (Hayat et al., 2010 and Mahdi et al., 2012).

Naphthalene acetic acid, commonly abbreviated NAA is an organic compound, which is a plant hormone in the auxin family that considered an ingredient in many commercial horticultural products. It has an important role in fruit formation, abscission cell elongation, apical dominance, photoperiod and geotropism and used for thinning of fruits to reduce alternate bearing, improving fruit quality and yield in various crops. (Agusti et al., 2000,
Krueger et al., 2004 ,Dimitrios et al., 2008 and Khankahdani et al., 2013) .

This study aimed to investigate the effect of foliar application of Naphthalene acetic acid (NAA) and Salicylic acid (SA) on enhancing flowering, controlling alternate bearing, improving yield and fruit quality of Picual and Manzanillo olive trees under south Egypt conditions.

\section{MATERIALS AND METHODS}

This study was carried out during three successive seasons of 2014, 2015 and 2016 on two olive cultivars namely, "Picual" and "Manzanillo" grown in Horticultural Station Orchard, situated at Shandaweel region, Sohag Governorate, Egypt. The experimental trees were about 11 years old $6 \times 6 \mathrm{~m}$ apart, cultivated in a silt clay loam soil under flood system, similar in growth vigor and received regular horticultural practices as recommended by Ministry of Agricultural.

\section{Experimental Work:}

Two tested cultivars Picual and Manzanillo were treated with two plant regulators namely Naphthalene acetic acid (NAA) and Salicylic acid (SA) as foliar application once on the first week of March (before beginning of the flowering) with five treatments as follow :

(1) Control (tap water)

(2) Spraying by Naphthalene acetic acid at $50 \mathrm{ppm}$

(3) Spraying by Naphthalene acetic acid of $100 \mathrm{ppm}$

(4) Spraying by Salicylic acid of $200 \mathrm{ppm}$

(5) Spraying by Salicylic acid of $400 \mathrm{ppm}$

Tween 20 was added at $0.1 \%$ as a surfactant to all spray solutions including the control "tap water". Spraying process was carried out using a compression sprays $(5 \mathrm{~L}$. solution/tree).

The experiment is considered a factorial experiment ( 2 cultivar $\mathrm{x}$ cultural treatments). The treatments were arranged in a completely randomized design with three replicates for each treatment and each replicate was represented by one tree.

The response of Picual and Manzanillo trees to the tested treatments was evaluated through the following measurements:

1- Flowering Behavior: Before beginning the flowering twenty shoots per tree was labeled to record the following parameters:

- Flowering Density: calculated according to the following equation 


$$
\text { Flowering density }(\%)=\frac{\mathrm{No} \text { of inflorescences }}{\text { shoot length }(\mathrm{cm})} \times 100
$$

- Average Number of flowers total and perfect flowers per inflorescence:

Twenty inflorescences at the middle portion of the shoot were chosen from inner and outer portion of the tree canopy to determine the number of total flowers and perfect flowers per inflorescence.

- Sex expression ratio: calculated by using the following equation:

Perfect flower percentage $=\frac{\text { Number of perfect flowers }}{\text { Number of total flowers }} \times 100$

2- Fruiting and Yield (kg / tree):

- Initial and final fruit set $(\%)$.

The percentage of initial fruit set (IFS \%) and final fruit set (FFS \%) was calculated after 21 days and 60 days of pollination as:

$$
\begin{aligned}
& \text { IFS \% }=\frac{\text { Number of fruitlets after } 21 \text { days }}{\text { Total number ofperfect flowers }} \times 100 \\
& \text { FFS } \%=\frac{\text { Number of fruit after todays }}{\text { Total number cf perfect flowers }} \times 100
\end{aligned}
$$

- Yield (kg/tree):

The average yield for each individual tree were recorded at harvesting time for each cultivar from each treatment in the three seasons as $(\mathrm{kg} /$ tree $)$.

Biennial bearing index: The index of alternate bearing for each cultivar of the different treated trees was estimated according to Wilcox (1944) as follows:

Biennial bearing index $=\underline{\text { Differences in vield }(\mathrm{kg}) \text { between successive vears }} \times 100$ Sum of yield $(\mathrm{kg})$ of successive years

3- Fruit Physical and chemical characteristics

50 fruits were picked randomly from all sides of each tree at harvest to determine the following fruit quality: fruit weight $(\mathrm{gm})$, flesh weight, flesh thickness (mm), Flesh/fruit weight (\%), stone weight (gm) and flesh: stone ratio (Fouad et al.,1992)

Fruit moisture content (\%) was calculated according to (A.O.A.C. 1990) and Fruit oil content as a dry weight was determined according to (A.O.A.C 1995) method.

\section{4- Leaves mineral content.}

- Leaves mineral content at mid: July of each season, twenty leaves from the middle portion at one year old shoot each replicate tree were taken, washed with tap water then with distilled water, dried at $70^{\circ} \mathrm{c}$ until constant weight, for determination of the following nutrient elements:

- Nitrogen was determined by the Microkjeldahl method (Pregl 1945).

- Phosphorous was estimated by the method described by (Murphy and Riely 1962).

- Potassium was flame-photometerically determined according to the method described by (Brown and Lilleland, 1946).

Statistical analysis:

The obtained data in the three seasons were subjected to statistical analysis of variance (ANOVA) and significant differences among means were determined according to (Snedecor and Cochran, 1972). In addition significant difference among means were distinguished according to the Duncan's, multiple test range (Duncan, 1955) whereas, capital and small letters were used for differentiating the values of specific and interaction effects of investigated factors, respectively.

\section{RESULTS AND DISCUSSION}

\section{Flowering Behavior:}

- Flowering density.

In regard to the flowering density that presented in Table (1), as the effect of Naphthalene acetic acid and Salicylic acid foliar application on Picual and Manzanillo cvs. and their interaction during 2014, 2015 and 2016 growing seasons, data preformed that, Manzanillo cv. gave the higher value in the first season. While, Picual cv. was superior in the third season. Moreover, no difference between cultivars in the second season. The maximum percentage of flowering density by Salicylic acid treatment at $200 \mathrm{ppm}$ in the three seasons compared to control and other treatments.

Table 1. Effect of foliar application of Naphthalene acetic acid (NAA) and Salicylic acid (SA) at different concentrations on flowering density percentage of Picual and Manzanillo cvs. during 2014, 2015 and 2016 seasons.

\begin{tabular}{lccccccccc}
\hline Cultivars & \multicolumn{3}{c}{$\mathbf{2 0 1 4}$} & \multicolumn{3}{c}{$\mathbf{2 0 1 5}$} & \multicolumn{2}{c}{$\mathbf{2 0 1 6}$} \\
\cline { 2 - 9 } Treatments & Picual & Manzanillo & Mean & Picual & Manzanillo & Mean & Picual & Manzanillo & Mean \\
\hline Control & $39.90^{\mathrm{h}}$ & $42.53^{\mathrm{g}}$ & $41.22^{\mathrm{E}}$ & $37.90^{\mathrm{j}}$ & $40.28^{\mathrm{i}}$ & $39.09^{\mathrm{E}}$ & $88.63^{\mathrm{c}}$ & $44.85^{\mathrm{g}}$ & $66.74^{\mathrm{D}}$ \\
NAA 50 ppm & $45.70^{\mathrm{f}}$ & $47.18^{\mathrm{d}}$ & $46.44^{\mathrm{D}}$ & $43.70^{\mathrm{g}}$ & $42.52^{\mathrm{h}}$ & $43.11^{\mathrm{D}}$ & $88.68^{\mathrm{c}}$ & $44.62^{\mathrm{g}}$ & $66.65^{\mathrm{D}}$ \\
NAA 100 ppm & $46.58^{\mathrm{e}}$ & $47.96^{\mathrm{c}}$ & $47.27^{\mathrm{C}}$ & $45.42^{\mathrm{e}}$ & $45.14^{\mathrm{f}}$ & $45.28^{\mathrm{C}}$ & $90.53^{\mathrm{b}}$ & $50.06^{\mathrm{f}}$ & $70.30^{\mathrm{C}}$ \\
SA 200 ppm & $48.14^{\mathrm{c}}$ & $49.41^{\mathrm{a}}$ & $48.78^{\mathrm{A}}$ & $47.27^{\mathrm{b}}$ & $48.24^{\mathrm{a}}$ & $47.76^{\mathrm{A}}$ & $94.06^{\mathrm{a}}$ & $57.26^{\mathrm{d}}$ & $75.66^{\mathrm{A}}$ \\
SA 400 ppm & $47.48^{\mathrm{d}}$ & $48.83^{\mathrm{b}}$ & $48.16^{\mathrm{B}}$ & $46.22^{\mathrm{d}}$ & $46.84^{\mathrm{c}}$ & $46.53^{\mathrm{B}}$ & $91.71^{\mathrm{b}}$ & $55.3^{\text {le }}$ & $73.51^{\mathrm{B}}$ \\
Mean & $45.56^{\mathrm{B}}$ & $47.19^{\mathrm{A}}$ & - & $44.11^{\mathrm{A}}$ & $44.61^{\mathrm{A}}$ & - & $90.72^{\mathrm{A}}$ & $50.42^{\mathrm{B}}$ & - \\
\hline
\end{tabular}

Mean separation within cultivars, treatments and for interaction within each season according to L.S.D. at 0.05 level.

Number of total flowers per inflorescence

Concerning the results that shown in table (2), it could be noticed that, there were significant differences between the Picual and Manzanillo cvs. during three studied seasons. Manzanillo cv. gave the higher values as compared with Picual in the three studied seasons. As the effect of foliar spraying treatments, The Salicylic acid treatment at $200 \mathrm{ppm}$ gave the highest number of total flowers per inflorescence during 2014, 2015 and 2016 seasons compared to the control. 
Table 2. Effect of foliar application of Naphthalene acetic acid (NAA) and Salicylic acid (SA) at different concentrations on number of total flowers per inflorescence of Picual and Manzanillo cvs. during 2014, 2015 and 2016 seasons.

\begin{tabular}{lccccccccc}
\hline Cultivars & \multicolumn{3}{c}{$\mathbf{2 0 1 4}$} & \multicolumn{3}{c}{$\mathbf{2 0 1 5}$} & \multicolumn{2}{c}{$\mathbf{2 0 1 6}$} \\
\cline { 2 - 9 } Treatments & Picual & Manzanillo & Mean & Picual & Manzanillo & Mean & Picual & Manzanillo & Mean \\
\hline Control & $3.55^{\mathrm{d}}$ & $8.44^{\mathrm{b}}$ & $6.00^{\mathrm{B}}$ & $2.9^{\mathrm{b}}$ & $4.450^{\mathrm{ab}}$ & $3.71^{\mathrm{B}}$ & $6.26^{\mathrm{d}}$ & $9.450^{\mathrm{c}}$ & $7.85^{\mathrm{B}}$ \\
NAA 50 ppm & $5.00^{\mathrm{cd}}$ & $9.89^{\mathrm{ab}}$ & $7.45^{\mathrm{A}}$ & $4.43^{\mathrm{ab}}$ & $5.91^{\mathrm{a}}$ & $5.17^{\mathrm{A}}$ & $11.63^{\mathrm{b}}$ & $14.82^{\mathrm{a}}$ & $13.23^{\mathrm{A}}$ \\
NAA 100 ppm & $5.13^{\mathrm{c}}$ & $10.02^{\mathrm{a}}$ & $7.58^{\mathrm{A}}$ & $4.56^{\mathrm{ab}}$ & $6.04^{\mathrm{a}}$ & $5.30^{\mathrm{A}}$ & $11.55^{\mathrm{b}}$ & $14.74^{\mathrm{a}}$ & $13.15^{\mathrm{A}}$ \\
SA 200 ppm & $5.30^{\mathrm{c}}$ & $10.19^{\mathrm{a}}$ & $7.74^{\mathrm{A}}$ & $4.70^{\mathrm{ab}}$ & $6.18^{\mathrm{a}}$ & $5.44^{\mathrm{A}}$ & $11.90^{\mathrm{b}}$ & $15.09^{\mathrm{a}}$ & $13.49^{\mathrm{A}}$ \\
SA 400 ppm & $5.20^{\mathrm{c}}$ & $10.09^{\mathrm{a}}$ & $7.65^{\mathrm{A}}$ & $4.60^{\mathrm{ab}}$ & $6.08^{\mathrm{a}}$ & $5.34^{\mathrm{A}}$ & $11.64^{\mathrm{b}}$ & $14.83^{\mathrm{a}}$ & $13.23^{\mathrm{A}}$ \\
Mean & $4.84^{\mathrm{B}}$ & $9.73^{\mathrm{A}}$ & - & $4.25^{\mathrm{B}}$ & $5.73^{\mathrm{A}}$ & - & $10.60^{\mathrm{B}}$ & $13.79^{\mathrm{A}}$ & - \\
\hline
\end{tabular}

Mean separation within cultivars, treatments and for interaction within each season according to L.S.D. at 0.05 level.

Number of perfect flowers per inflorescence:

Regarding to the effect of cultivar and spraying treatments on the in number of perfect flowers per inflorescence, data in Table (3), preformed that, Manzanillo cv. gave the higher value than Picual cv. in the first and second season while insignificant differences the third season was indicated. In addition, the tested Naphthalene acetic acid and Salicylic acid foliar application indicated significant differences among them in number of perfect flowers per inflorescence in the first and second seasons except the third season indicated insignificant differences. Moreover, the Salicylic acid treatment at 200 ppm gave the highest numbers of perfect flowers per inflorescence in the three growing seasons compared to tested treatments.

Table 3. Effect of foliar application of Naphthalene acetic acid (NAA) and Salicylic acid (SA) at different concentrations on the number of perfect flowers per inflorescence of Picual and Manzanillo cvs. during 2014, 2015 and 2016 seasons.

\begin{tabular}{lccccccccc}
\hline Cultivars & \multicolumn{3}{c}{$\mathbf{2 0 1 4}$} & \multicolumn{3}{c}{$\mathbf{2 0 1 5}$} & \multicolumn{2}{c}{$\mathbf{2 0 1 6}$} \\
\cline { 2 - 9 } Treatments & Picual & Manzanillo & Mean & Picual & Manzanillo & Mean & Picual & Manzanillo & Mean \\
\hline Control & $2.65^{\mathrm{c}}$ & $5.46^{\mathrm{ab}}$ & $4.06^{\mathrm{B}}$ & $2.20^{1}$ & $2.54^{\mathrm{h}}$ & $2.37^{\mathrm{E}}$ & $4.79^{\mathrm{b}}$ & $6.14^{\mathrm{b}}$ & $5.47^{\mathrm{B}}$ \\
NAA 50 ppm & $3.82^{\mathrm{bc}}$ & $6.57^{\mathrm{a}}$ & $5.20^{\mathrm{AB}}$ & $3.35^{\mathrm{g}}$ & $3.47^{\mathrm{f}}$ & $3.41^{\mathrm{D}}$ & $9.11^{\mathrm{a}}$ & $9.90^{\mathrm{a}}$ & $9.51^{\mathrm{A}}$ \\
NAA 100 ppm & $3.92^{\mathrm{bc}}$ & $6.6^{\mathrm{a}}$ & $5.29^{\mathrm{A}}$ & $3.45^{\mathrm{f}}$ & $3.55^{\mathrm{d}}$ & $3.50^{\mathrm{C}}$ & $9.05^{\mathrm{a}}$ & $9.85^{\mathrm{a}}$ & $9.45^{\mathrm{A}}$ \\
SA 200 ppm & $4.14^{\mathrm{bc}}$ & $6.95^{\mathrm{a}}$ & $5.54^{\mathrm{A}}$ & $3.63^{\mathrm{b}}$ & $3.73^{\mathrm{a}}$ & $3.68^{\mathrm{A}}$ & $9.52^{\mathrm{a}}$ & $10.33^{\mathrm{a}}$ & $9.92^{\mathrm{A}}$ \\
SA 400 ppm & $3.98^{\mathrm{bc}}$ & $6.72^{\mathrm{a}}$ & $5.35^{\mathrm{A}}$ & $3.49^{\mathrm{e}}$ & $3.59^{\mathrm{c}}$ & $3.54^{\mathrm{B}}$ & $9.14^{\mathrm{a}}$ & $9.93^{\mathrm{a}}$ & $9.54^{\mathrm{A}}$ \\
Mean & $3.70^{\mathrm{B}}$ & $6.47^{\mathrm{A}}$ & - & $3.22^{\mathrm{B}}$ & $3.37^{\mathrm{A}}$ & - & $8.32^{\mathrm{A}}$ & $9.23^{\mathrm{A}}$ & - \\
\hline
\end{tabular}

Mean separation within cultivars, treatments and for interaction within each season according to L.S.D. at 0.05 level.

- Perfect flower percentage.

As shown in Table (4) it could be noticed that, Picual cv. gave the higher sex expression ratio comparing to Manzanillo cv. in the three studied seasons. Similarly, data appeared that, the tested Naphthalene acetic acid (NAA) and Salicylic acid (SA) foliar application indicated significant differences among them in sex expression ratio in the second and third seasons except in the first season. The Salicylic acid (SA) treatment at $200 \mathrm{ppm}$ significantly gave the highest percentage of perfect flower percentage, compared to the experimental treatments in the second and third seasons.

Table 4. Effect of foliar application of Naphthalene acetic acid (NAA) and Salicylic acid (SA) at different concentrations perfect flower percentage of Picual and Manzanillo cvs. during 2014, 2015 and 2016 seasons.

\begin{tabular}{lccccccccc}
\hline Cultivars & \multicolumn{3}{c}{$\mathbf{2 0 1 4}$} & \multicolumn{3}{c}{$\mathbf{2 0 1 5}$} & \multicolumn{2}{c}{$\mathbf{2 0 1 6}$} \\
\cline { 2 - 9 } Treatments & Picual & Manzanillo & Mean & Picual & Manzanillo & Mean & Picual & Manzanillo & Mean \\
\hline Control & $74.65^{\mathrm{a}}$ & $64.69^{\mathrm{b}}$ & $69.67^{\mathrm{A}}$ & $74.07^{\mathrm{b}}$ & $57.08^{\mathrm{d}}$ & $65.58^{\mathrm{C}}$ & $76.52^{\mathrm{c}}$ & $64.97^{\mathrm{f}}$ & $70.75^{\mathrm{C}}$ \\
NAA 50 ppm & $76.4^{\mathrm{a}}$ & $66.43^{\mathrm{b}}$ & $71.42^{\mathrm{A}}$ & $75.62^{\mathrm{ab}}$ & $58.71^{\mathrm{cd}}$ & $67.17^{\mathrm{B}}$ & $78.33^{\mathrm{b}}$ & $66.80^{\mathrm{e}}$ & $72.57^{\mathrm{B}}$ \\
NAA 100 ppm & $76.41^{\mathrm{a}}$ & $66.47^{\mathrm{b}}$ & $71.44^{\mathrm{A}}$ & $75.66^{\mathrm{ab}}$ & $58.77^{\mathrm{cd}}$ & $67.22^{\mathrm{B}}$ & $78.35^{\mathrm{b}}$ & $66.82^{\mathrm{e}}$ & $72.59^{\mathrm{B}}$ \\
SA 200 ppm & $78.11^{\mathrm{a}}$ & $68.20^{\mathrm{b}}$ & $73.16^{\mathrm{A}}$ & $77.23^{\mathrm{a}}$ & $60.36^{\mathrm{c}}$ & $68.80^{\mathrm{A}}$ & $80.00^{\mathrm{a}}$ & $68.46^{\mathrm{d}}$ & $74.23^{\mathrm{A}}$ \\
SA 400 ppm & $76.54^{\mathrm{a}}$ & $66.60^{\mathrm{b}}$ & $71.57^{\mathrm{A}}$ & $75.87^{\mathrm{ab}}$ & $59.05^{\mathrm{c}}$ & $67.46^{\mathrm{B}}$ & $78.52^{\mathrm{b}}$ & $66.96^{\mathrm{e}}$ & $72.74^{\mathrm{B}}$ \\
Mean & $76.42^{\mathrm{A}}$ & $66.48^{\mathrm{B}}$ & - & $75.69^{\mathrm{A}}$ & $58.79^{\mathrm{B}}$ & - & $78.35^{\mathrm{A}}$ & $66.80^{\mathrm{B}}$ & - \\
\hline
\end{tabular}

Mean separation within cultivars, treatments and for interaction within each season according to L.S.D. at 0.05 level.

Fruiting and yield:

Date presented in Tables (5, 6, 7 and 8) observed the effect of cultivar (Picual and Manzanillo) and treatments by Naphthalene acetic acid (NAA) and Salicylic acid (SA) foliar application on initial fruit set percentage, final fruit set percentage and yield (kg./tree) and their interaction during 2014, 2015 and 2016 growing seasons.

Initial and final fruit set (\%).

As for initial fruit set percentage in Tables (5and 6), data revealed that, there were significant differences between the Picual and Manzanillo cvs. in the three season. Manzanillo cv. gave significantly the higher value in the first and third seasons. While, Picual cv. gave the higher value in the second season in initial and final fruit set percentage. Concerning the effect of treatments in the initial fruit set, salicylic acid at $200 \mathrm{ppm}$ was superior in the three studied seasons although Naphthalene acetic acid at 50 ppm gave the same effect in the first season. Regarding the final fruit set percentage, there were statically convergence between spraying treatments, but salicylic acid application at 200 ppm was the best. On the other hand control treatment recorded the lowest one during three studied seasons for both initial and final fruit set. 
Table 5. Effect of foliar application of Naphthalene acetic acid (NAA) and Salicylic acid (SA) at different concentrations on initial fruit set percentage of Picual and Manzanillo cvs. during 2014, 2015 and 2016 seasons.

\begin{tabular}{lccccccccc}
\hline Cultivars & \multicolumn{3}{c}{$\mathbf{2 0 1 4}$} & \multicolumn{3}{c}{$\mathbf{2 0 1 5}$} & \multicolumn{2}{c}{$\mathbf{2 0 1 6}$} \\
\cline { 2 - 9 } Treatments & Picual & Manzanillo & Mean & Picual & Manzanillo & Mean & Picual & Manzanillo & Mean \\
\hline Control & $32.46^{\mathrm{f}}$ & $39.36^{\mathrm{d}}$ & $35.91^{\mathrm{D}}$ & $30.65^{\mathrm{C}}$ & $21.43^{\mathrm{f}}$ & $26.04^{\mathrm{E}}$ & $50.05^{\mathrm{g}}$ & $58.11^{\mathrm{de}}$ & $54.08^{\mathrm{E}}$ \\
NAA 50 ppm & $43.16^{\mathrm{c}}$ & $50.06^{\mathrm{a}}$ & $46.61^{\mathrm{A}}$ & $34.47^{\mathrm{b}}$ & $25.25^{\mathrm{e}}$ & $29.86^{\mathrm{B}}$ & $57.56^{\mathrm{ef}}$ & $65.62^{\mathrm{b}}$ & $61.59^{\mathrm{B}}$ \\
NAA 100 ppm & $39.76^{\mathrm{d}}$ & $46.66^{\mathrm{b}}$ & $43.21^{\mathrm{B}}$ & $33.58^{\mathrm{b}}$ & $24.3^{\mathrm{e}}$ & $28.97^{\mathrm{C}}$ & $56.26^{\mathrm{f}}$ & $64.32^{\mathrm{b}}$ & $60.29^{\mathrm{C}}$ \\
SA 200 ppm & $43.66^{\mathrm{c}}$ & $50.56^{\mathrm{a}}$ & $47.11^{\mathrm{A}}$ & $35.66^{\mathrm{a}}$ & $26.44^{\mathrm{d}}$ & $31.05^{\mathrm{A}}$ & $60.76^{\mathrm{c}}$ & $68.82^{\mathrm{a}}$ & $64.79^{\mathrm{A}}$ \\
SA 400 ppm & $35.86^{\mathrm{e}}$ & $42.83^{\mathrm{c}}$ & $39.35^{\mathrm{C}}$ & $31.50^{\mathrm{c}}$ & $22.28^{\mathrm{H}}$ & $26.89^{\mathrm{D}}$ & $51.31^{\mathrm{g}}$ & $59.37^{\mathrm{cd}}$ & $55.34^{\mathrm{D}}$ \\
Mean & $38.98^{\mathrm{B}}$ & $45.89^{\mathrm{A}}$ & - & $33.17^{\mathrm{A}}$ & $23.95^{\mathrm{B}}$ & - & $55.19^{\mathrm{B}}$ & $63.25^{\mathrm{A}}$ & - \\
\hline
\end{tabular}

Mean separation within cultivars, treatments and for interaction within each season according to L.S.D. at 0.05 level.

Table 6. Effect of foliar application of Naphthalene acetic acid and Salicylic acid at different concentrations on final fruit set percentage of Picual and Manzanillo cvs. during 2014, 2015 and 2016 seasons.

\begin{tabular}{lccccccccc}
\hline Cultivars & \multicolumn{3}{c}{$\mathbf{2 0 1 4}$} & \multicolumn{3}{c}{$\mathbf{2 0 1 5}$} & \multicolumn{2}{c}{$\mathbf{2 0 1 6}$} \\
\cline { 2 - 9 } Treatments & Picual & Manzanillo & Mean & Picual & Manzanillo & Mean & Picual & Manzanillo & Mean \\
\hline Control & $28.85^{\mathrm{b}}$ & $35.75^{\mathrm{a}}$ & $32.30^{\mathrm{B}}$ & $27.84^{\mathrm{a}}$ & $18.62^{\mathrm{b}}$ & $23.23^{\mathrm{B}}$ & $41.80^{\mathrm{b}}$ & $49.86^{\mathrm{a}}$ & $45.83^{\mathrm{B}}$ \\
NAA 50 ppm & $29.83^{\mathrm{b}}$ & $36.73^{\mathrm{a}}$ & $33.28^{\mathrm{AB}}$ & $28.51^{\mathrm{a}}$ & $19.29^{\mathrm{b}}$ & $23.90^{\mathrm{AB}}$ & $42.99^{\mathrm{b}}$ & $51.05^{\mathrm{a}}$ & $47.02^{\mathrm{AB}}$ \\
NAA 100 ppm & $29.63^{\mathrm{b}}$ & $36.53^{\mathrm{a}}$ & $33.08^{\mathrm{AB}}$ & $28.35^{\mathrm{a}}$ & $19.13^{\mathrm{b}}$ & $23.74^{\mathrm{AB}}$ & $42.67^{\mathrm{b}}$ & $50.73^{\mathrm{a}}$ & $46.70^{\mathrm{AB}}$ \\
SA 200 ppm & $30.26^{\mathrm{b}}$ & $37.16^{\mathrm{a}}$ & $33.71^{\mathrm{A}}$ & $28.84^{\mathrm{a}}$ & $19.62^{\mathrm{b}}$ & $24.23^{\mathrm{A}}$ & $43.62^{\mathrm{b}}$ & $51.68^{\mathrm{a}}$ & $47.65^{\mathrm{A}}$ \\
SA 400 ppm & $29.05^{\mathrm{b}}$ & $35.95^{\mathrm{a}}$ & $32.50^{\mathrm{AB}}$ & $28.02^{\mathrm{a}}$ & $18.80^{\mathrm{b}}$ & $23.41^{\mathrm{AB}}$ & $42.15^{\mathrm{b}}$ & $50.41^{\mathrm{a}}$ & $46.48^{\mathrm{AB}}$ \\
Mean & $29.53^{\mathrm{B}}$ & $36.43^{\mathrm{A}}$ & - & $28.31^{\mathrm{A}}$ & $19.09^{\mathrm{B}}$ & - & $42.65^{\mathrm{B}}$ & $50.82^{\mathrm{A}}$ & - \\
\hline
\end{tabular}

Mean separation within cultivars, treatments and for interaction within each season according to L.S.D. at 0.05 level.

Yield crop (kg/tree):

As related to data in Table (7) it was noticed that, the production of Manzanillo cv. surpassed Picual cv. during 2014 and 2015 seasons in the positive. While no significant difference during 2016 between two studied cultivars. Foliar application with salicylic acid at $200 \mathrm{ppm}$ gave enhanced yield comparing with other treatments and control.

Table 7. Effect of foliar application of Naphthalene acetic acid (NAA) and Salicylic acid (SA) at different concentrations on fruit yield (kg/tree) of Picual and Manzanillo cvs. during 2014, 2015 and 2016 seasons.

\begin{tabular}{lccccccccc}
\hline Cultivars & \multicolumn{3}{c}{$\mathbf{2 0 1 4}$} & \multicolumn{3}{c}{$\mathbf{2 0 1 5}$} & \multicolumn{2}{c}{$\mathbf{2 0 1 6}$} \\
\cline { 2 - 9 } Treatments & Picual & Manzanillo & Mean & Picual & Manzanillo & Mean & Picual & Manzanillo & Mean \\
\hline Control & $38.03^{\mathrm{g}}$ & $43.28^{\mathrm{f}}$ & $40.66^{\mathrm{D}}$ & $25.31^{\mathrm{i}}$ & $30.06^{\mathrm{fg}}$ & $27.69^{\mathrm{E}}$ & $46.35^{\mathrm{f}}$ & $45.60^{\mathrm{f}}$ & $45.97^{\mathrm{D}}$ \\
NAA 50 ppm & $42.97^{\mathrm{f}}$ & $47.97^{\mathrm{bc}}$ & $45.47^{\mathrm{C}}$ & $27.03^{\mathrm{h}}$ & $32.03^{\mathrm{de}}$ & $29.53^{\mathrm{D}}$ & $46.37^{\mathrm{f}}$ & $45.37^{\mathrm{f}}$ & $45.87^{\mathrm{D}}$ \\
NAA 100 ppm & $44.25^{\text {ef }}$ & $48.75^{\mathrm{ab}}$ & $46.50^{\mathrm{BC}}$ & $29.15^{\mathrm{g}}$ & $34.65^{\mathrm{c}}$ & $31.90^{\mathrm{C}}$ & $50.15^{\mathrm{d}}$ & $48.65^{\mathrm{e}}$ & $49.40^{\mathrm{C}}$ \\
SA 200 ppm & $46.56^{\mathrm{cd}}$ & $50.21^{\mathrm{a}}$ & $48.39^{\mathrm{A}}$ & $32.90^{\mathrm{d}}$ & $39.25^{\mathrm{a}}$ & $36.08^{\mathrm{A}}$ & $57.20^{\mathrm{a}}$ & $54.85^{\mathrm{b}}$ & $56.03^{\mathrm{A}}$ \\
SA 400 ppm & $45.22^{\text {de }}$ & $49.62^{\mathrm{a}}$ & $47.42^{\mathrm{AB}}$ & $30.80^{\text {ef }}$ & $36.40^{\mathrm{b}}$ & $33.60^{\mathrm{B}}$ & $52.50^{\mathrm{c}}$ & $50.90^{\mathrm{d}}$ & $51.70^{\mathrm{B}}$ \\
Mean & $43.41^{\mathrm{B}}$ & $47.97^{\mathrm{A}}$ & - & $29.04^{\mathrm{B}}$ & $34.48^{\mathrm{A}}$ & - & $50.51^{\mathrm{A}}$ & $49.07^{\mathrm{A}}$ & - \\
\hline
\end{tabular}

Mean separation within cultivars, treatments and for interaction within each season according to L.S.D. at 0.05 level.

Alternate bearing index.

Concerning the effect of cultivar and treatment on Alternate bearing. Data in Table (8) revealed that biennial bearing index of Manzanillo cv. was less than Picual cv., and each of Salicylic acid (200 \& $400 \mathrm{ppm})$ reduced the alternate bearing comparing with the treatments with Naphthalene acetic acid at $50 \& 100 \mathrm{ppm}$ and the control in the studied seasons.

Table 8. Effect of foliar application of Naphthalene acetic acid (NAA) and Salicylic acid (SA) at different concentrations on alternate bearing index of Picual and Manzanillo cvs. during 2014, 2015 and 2016 seasons.

Cultivars

\begin{tabular}{lccc}
\cline { 2 - 3 } Treatments & Picual & Manzanillo & Mean \\
\hline Control & $0.25^{\mathrm{a}}$ & $0.19^{\mathrm{c}}$ & $0.22^{\mathrm{A}}$ \\
NAA 50 ppm & $0.25^{\mathrm{a}}$ & $0.19^{\mathrm{c}}$ & $0.22^{\mathrm{A}}$ \\
NAA 100 ppm & $0.24^{\mathrm{ab}}$ & $0.17^{\mathrm{d}}$ & $0.20^{\mathrm{B}}$ \\
SA 200 ppm & $0.22^{\mathrm{b}}$ & $0.15^{\mathrm{e}}$ & $0.18^{\mathrm{C}}$ \\
SA 400 ppm & $0.23^{\mathrm{b}}$ & $0.16^{\mathrm{de}}$ & $0.19^{\mathrm{BC}}$ \\
Mean & $0.24^{\mathrm{A}}$ & $0.17^{\mathrm{B}}$ & - \\
\hline
\end{tabular}

Mean separation within cultivars, treatments and for interaction within each season according to L.S.D. at 0.05 level.
By using the equation suggested by Wilcox (1944), it is evident that all studied olive cultivars (Picual and Manzanillo cvs.) between 2014 and 2016 seasons were characterized by regular bearing because the alternate bearing index was less than $25 \%$.

Fruit physical characteristics:

Foliar application treatments had pronounced effect on improving fruit quality. The results in Tables (from 9 to 14) demonstrated the fruit physical characteristics (fruit weight, flesh weight, flesh thickness, stone weight, flesh per fruit weight (\%), and flesh: stone ratio), as affected by Naphthalene acetic acid (NAA) and Salicylic acid (SA) of Picual and Manzanillo cvs. and their interaction during 2014, 2015 and 2016 growing seasons. Concerning the effect of the treatments, although there weren't any significant difference of fruit weight, flesh weight and flesh thickness of Manzanillo and Picual cvs. during three studied seasons. Meantime, foliar spray with Salicylic acid at $200 \mathrm{ppm}$ was affected significantly on fruit weight, flesh weight, while each of concentrations (200 and $400 \mathrm{ppm}$ ) of Salicylic acid affected significantly on flesh thickness followed by other treatments. 
As for stone weight in Table (12) foliar application of Naphthalene acetic acid (NAA) and Salicylic acid (SA) gave the same effect on Picual and Manzanillo cvs. during 2014, 2015 and 2016 seasons. Furthermore, results appeared that, Salicylic acid foliar application at $200 \mathrm{ppm}$ indicated the highest stone weight in the first and third seasons. Whereas, there were insignificant differences among the treatments in the second season. The control treatment significantly gave the lowest stone weight.

In regard to flesh per fruit weight percentage of Picual and Manzanillo cvs. in Table (13) as affected by aforementioned treatments. It is obvious that, there were no apparent effect on cultivars during three studied seasons. The maximum flesh per fruit weight percentage was observed in Salicylic acid. treatment at 200 ppm compared to the control and other treatments in the three seasons.

Concerning to flesh per stone ratio in Table (14) as affected by Naphthalene acetic acid and Salicylic acid foliar application on Picual and Manzanillo cvs. and their interaction during 2014, 2015 and 2016 growing seasons. Data preformed that, there were insignificant differences between cultivars in the first and third seasons. While Picual cv. was superior in the second season. Regarding to the effect of treatments, The Salicylic acid (SA) at 200 ppm significantly gave the highest flesh per stone ratio respectively in the three seasons comparing with other treatments and control.

Table 9. Effect of foliar application of Naphthalene acetic acid (NAA) and Salicylic acid (SA) at different concentrations on fruit weight (g) of Picual and Manzanillo cvs. during 2014, 2015 and 2016 seasons.

\begin{tabular}{lccccccccc}
\hline Cultivars & \multicolumn{3}{c}{$\mathbf{2 0 1 4}$} & \multicolumn{3}{c}{$\mathbf{2 0 1 5}$} & \multicolumn{2}{c}{$\mathbf{2 0 1 6}$} \\
\cline { 2 - 9 } Treatments & Picual & Manzanillo & Mean & Picual & Manzanillo & Mean & Picual & Manzanillo & Mean \\
\hline Control & $3.29^{1}$ & $3.91^{\mathrm{g}}$ & $3.60^{\mathrm{E}}$ & $5.10^{\mathrm{de}}$ & $4.48^{\mathrm{e}}$ & $4.79^{\mathrm{D}}$ & $3.82^{\mathrm{J}}$ & $4.17^{\mathrm{1}}$ & $4.00^{\mathrm{E}}$ \\
NAA 50 ppm & $3.63^{\mathrm{h}}$ & $4.25^{\mathrm{f}}$ & $3.94^{\mathrm{D}}$ & $5.45^{\mathrm{cd}}$ & $4.83^{\mathrm{de}}$ & $5.14^{\mathrm{CD}}$ & $4.25^{\mathrm{h}}$ & $4.44^{\mathrm{g}}$ & $4.35^{\mathrm{D}}$ \\
NAA 100 ppm & $4.54^{\mathrm{e}}$ & $5.16^{\mathrm{d}}$ & $4.85^{\mathrm{C}}$ & $6.38^{\mathrm{bd}}$ & $5.76^{\mathrm{ce}}$ & $6.07^{\mathrm{BC}}$ & $4.94^{\mathrm{f}}$ & $5.36^{\mathrm{e}}$ & $5.15^{\mathrm{C}}$ \\
SA 200 ppm & $6.32^{\mathrm{b}}$ & $6.94^{\mathrm{a}}$ & $6.63^{\mathrm{A}}$ & $8.37^{\mathrm{a}}$ & $7.75^{\mathrm{ab}}$ & $8.06^{\mathrm{A}}$ & $6.77^{\mathrm{b}}$ & $7.09^{\mathrm{a}}$ & $6.93^{\mathrm{A}}$ \\
SA 400 ppm & $5.26^{\mathrm{d}}$ & $5.8^{\mathrm{c}}$ & $5.57^{\mathrm{B}}$ & $7.10^{\mathrm{ac}}$ & $6.48^{\mathrm{bd}}$ & $6.79^{\mathrm{B}}$ & $5.65^{\mathrm{d}}$ & $6.06^{\mathrm{C}}$ & $5.86^{\mathrm{B}}$ \\
Mean & $4.61^{\mathrm{A}}$ & $5.23^{\mathrm{A}}$ & - & $6.48^{\mathrm{A}}$ & $5.86^{\mathrm{A}}$ & - & $5.09^{\mathrm{A}}$ & $5.43^{\mathrm{A}}$ & - \\
\hline
\end{tabular}

Mean separation within cultivars, treatments and for interaction within each season according to L.S.D. at 0.05 level.

Table 10. Effect of naphthalene acetic acid (NAA) and salicylic acid (SA) foliar application of at different concentrations on flesh weight (g) of Picual and Manzanillo cvs. during 2014, 2015 and 2016 seasons.

\begin{tabular}{lccccccccc}
\hline Cultivars & \multicolumn{3}{c}{$\mathbf{2 0 1 4}$} & \multicolumn{3}{c}{$\mathbf{2 0 1 5}$} & \multicolumn{2}{c}{$\mathbf{2 0 1 6}$} \\
\cline { 2 - 9 } Treatments & Picual & Manzanillo & Mean & Picual & Manzanillo & Mean & Picual & Manzanillo & Mean \\
\hline Control & $2.54^{\mathrm{e}}$ & $3.09^{\mathrm{de}}$ & $2.82^{\mathrm{D}}$ & $3.95^{\mathrm{de}}$ & $3.24^{\mathrm{e}}$ & $3.60^{\mathrm{D}}$ & $2.93^{\mathrm{d}}$ & $3.20^{\mathrm{cd}}$ & $3.07^{\mathrm{C}}$ \\
NAA 50 ppm & $2.80^{\mathrm{de}}$ & $3.35^{\mathrm{c}}$ & $3.08^{\mathrm{CD}}$ & $4.22^{\mathrm{de}}$ & $3.51^{\mathrm{e}}$ & $3.87^{\mathrm{CD}}$ & $3.32^{\mathrm{cd}}$ & $3.43^{\mathrm{cd}}$ & $3.37^{\mathrm{C}}$ \\
NAA 100 ppm & $3.64^{\mathrm{ce}}$ & $4.19^{\mathrm{bd}}$ & $3.91^{\mathrm{BC}}$ & $5.06^{\mathrm{bd}}$ & $4.35^{\mathrm{ce}}$ & $4.71^{\mathrm{BC}}$ & $3.94^{\text {bd }}$ & $4.28^{\text {ad }}$ & $4.10^{\mathrm{BC}}$ \\
SA 200 ppm & $5.27^{\mathrm{ab}}$ & $5.82^{\mathrm{a}}$ & $5.55^{\mathrm{A}}$ & $6.90^{\mathrm{a}}$ & $6.19^{\mathrm{ab}}$ & $6.55^{\mathrm{A}}$ & $5.86^{\mathrm{ab}}$ & $5.90^{\mathrm{a}}$ & $5.78^{\mathrm{A}}$ \\
SA 400 ppm & $4.29^{\mathrm{ad}}$ & $4.84^{\mathrm{ac}}$ & $4.56^{\mathrm{AB}}$ & $5.71^{\mathrm{ac}}$ & $5.00^{\mathrm{bd}}$ & $5.35^{\mathrm{B}}$ & $4.59^{\mathrm{ad}}$ & $4.92^{\mathrm{ac}}$ & $4.75^{\mathrm{AB}}$ \\
Mean & $3.71^{\mathrm{A}}$ & $4.26^{\mathrm{A}}$ & - & $5.17^{\mathrm{A}}$ & $4.46^{\mathrm{A}}$ & - & $4.29^{\mathrm{A}}$ & $4.35^{\mathrm{A}}$ & -
\end{tabular}

Mean separation within cultivars, treatments and for interaction within each season according to L.S.D. at 0.05 level.

Table 11. Effect of foliar application of Naphthalene acetic acid (NAA) and Salicylic acid (SA) at different concentrations on flesh thickness (mm) of Picual and Manzanillo cvs. during 2014, 2015 and 2016 seasons.

\begin{tabular}{lccccccccc}
\hline Cultivars & \multicolumn{3}{c}{$\mathbf{2 0 1 4}$} & \multicolumn{3}{c}{$\mathbf{2 0 1 5}$} & \multicolumn{2}{c}{$\mathbf{2 0 1 6}$} \\
\cline { 2 - 9 } Treatments & Picual & Manzanillo & Mean & Picual & Manzanillo & Mean & Picual & Manzanillo & Mean \\
\hline Control & $0.34^{\mathrm{g}}$ & $0.48^{\mathrm{d}}$ & $0.41^{\mathrm{D}}$ & $0.50^{\mathrm{J}}$ & $0.70^{\mathrm{e}}$ & $0.60^{\mathrm{E}}$ & $0.34^{\mathrm{e}}$ & $0.51^{\mathrm{c}}$ & $0.43^{\mathrm{C}}$ \\
NAA 50 ppm & $0.37^{\mathrm{f}}$ & $0.50^{\mathrm{c}}$ & $0.43^{\mathrm{C}}$ & $0.53^{\mathrm{i}}$ & $0.72^{\mathrm{d}}$ & $0.63^{\mathrm{D}}$ & $0.33^{\mathrm{e}}$ & $0.50^{\mathrm{C}}$ & $0.42^{\mathrm{C}}$ \\
NAA 100 ppm & $0.44^{\mathrm{e}}$ & $0.57^{\mathrm{b}}$ & $0.50^{\mathrm{B}}$ & $0.56^{\mathrm{h}}$ & $0.75^{\mathrm{c}}$ & $0.66^{\mathrm{C}}$ & $0.33^{\mathrm{e}}$ & $0.50^{\mathrm{c}}$ & $0.42^{\mathrm{C}}$ \\
SA 200 ppm & $0.44^{\mathrm{e}}$ & $0.58^{\mathrm{b}}$ & $0.51^{\mathrm{B}}$ & $0.58^{\mathrm{g}}$ & $0.78^{\mathrm{b}}$ & $0.68^{\mathrm{B}}$ & $0.40^{\mathrm{c}}$ & $0.66^{\mathrm{a}}$ & $0.58^{\mathrm{A}}$ \\
SA 400 ppm & $0.48^{\mathrm{d}}$ & $0.62^{\mathrm{a}}$ & $0.55^{\mathrm{A}}$ & $0.60^{\mathrm{f}}$ & $0.80^{\mathrm{a}}$ & $0.70^{\mathrm{A}}$ & $0.46^{\mathrm{d}}$ & $0.63^{\mathrm{b}}$ & $0.55^{\mathrm{B}}$ \\
Mean & $0.41^{\mathrm{A}}$ & $0.55^{\mathrm{A}}$ & - & $0.56^{\mathrm{A}}$ & $0.75^{\mathrm{A}}$ & - & $0.39^{\mathrm{A}}$ & $0.56^{\mathrm{A}}$ & - \\
\hline
\end{tabular}

Mean separation within cultivars, treatments and for interaction within each season according to L.S.D. at 0.05 level.

Table 12. Effect of foliar application of Naphthalene acetic acid (NAA) and Salicylic acid (SA) at different concentrations on stone weight (g) of Picual and Manzanillo cvs. during 2014, 2015 and 2016 seasons.

\begin{tabular}{lccccccccc}
\hline Cultivars & \multicolumn{3}{c}{$\mathbf{2 0 1 4}$} & \multicolumn{3}{c}{$\mathbf{2 0 1 5}$} & \multicolumn{2}{c}{$\mathbf{2 0 1 6}$} \\
\cline { 2 - 10 } Treatments & Picual & Manzanillo & Mean & Picual & Manzanillo & Mean & Picual & Manzanillo & Mean \\
\hline Control & $0.75^{\mathrm{f}}$ & $0.82^{\mathrm{e}}$ & $0.79^{\mathrm{E}}$ & $1.15^{\mathrm{a}}$ & $1.24^{\mathrm{a}}$ & $1.20^{\mathrm{A}}$ & $0.89^{\mathrm{g}}$ & $0.97^{\mathrm{ef}}$ & $0.93^{\mathrm{D}}$ \\
NAA 50 ppm & $0.83^{\mathrm{e}}$ & $0.90^{\mathrm{d}}$ & $0.86^{\mathrm{D}}$ & $1.23^{\mathrm{a}}$ & $1.32^{\mathrm{a}}$ & $1.27^{\mathrm{A}}$ & $0.93^{\mathrm{fg}}$ & $1.01^{\mathrm{de}}$ & $0.97^{\mathrm{D}}$ \\
NAA 100 ppm & $0.90^{\mathrm{d}}$ & $0.97^{\mathrm{c}}$ & $0.94^{\mathrm{C}}$ & $1.32^{\mathrm{a}}$ & $1.41^{\mathrm{a}}$ & $1.37^{\mathrm{A}}$ & $1.00^{\mathrm{e}}$ & $1.08^{\mathrm{c}}$ & $1.04^{\mathrm{C}}$ \\
SA 200 ppm & $1.05^{\mathrm{b}}$ & $1.12^{\mathrm{a}}$ & $1.09^{\mathrm{A}}$ & $1.47^{\mathrm{a}}$ & $1.56^{\mathrm{a}}$ & $1.52^{\mathrm{A}}$ & $1.11^{\mathrm{bc}}$ & $1.19^{\mathrm{a}}$ & $1.15^{\mathrm{A}}$ \\
SA 400 ppm & $0.97^{\mathrm{c}}$ & $1.04^{\mathrm{b}}$ & $1.01^{\mathrm{B}}$ & $1.39^{\mathrm{a}}$ & $1.48^{\mathrm{a}}$ & $1.44^{\mathrm{A}}$ & $1.06^{\mathrm{cd}}$ & $1.14^{\mathrm{ab}}$ & $1.10^{\mathrm{B}}$ \\
Mean & $0.90^{\mathrm{A}}$ & $0.97^{\mathrm{A}}$ & - & $1.31^{\mathrm{A}}$ & $1.40^{\mathrm{A}}$ & - & $1.00^{\mathrm{A}}$ & $1.08^{\mathrm{A}}$ & - \\
\hline
\end{tabular}

Mean separation within cultivars, treatments and for interaction within each season according to L.S.D. at 0.05 level. 
Table 13. Effect of foliar application of Naphthalene acetic acid (NAA) and Salicylic acid (SA) at different concentrations on flesh per fruit weight percentage of Picual and Manzanillo cvs. during 2014, 2015 and 2016 seasons.

\begin{tabular}{lccccccccc}
\hline Cultivars & \multicolumn{3}{c}{$\mathbf{2 0 1 4}$} & \multicolumn{3}{c}{$\mathbf{2 0 1 5}$} & \multicolumn{2}{c}{$\mathbf{2 0 1 6}$} \\
\cline { 2 - 9 } Treatments & Picual & Manzanillo & Mean & Picual & Manzanillo & Mean & Picual & Manzanillo & Mean \\
\hline Control & $77.20^{1}$ & $79.03^{\mathrm{g}}$ & $78.12^{\mathrm{D}}$ & $77.45^{\mathrm{e}}$ & $72.32^{\mathrm{j}}$ & $74.89^{\mathrm{E}}$ & $76.70^{\mathrm{e}}$ & $76.74^{\mathrm{e}}$ & $76.72^{\mathrm{E}}$ \\
NAA 50 ppm & $77.13^{\mathrm{j}}$ & $78.82^{\mathrm{h}}$ & $77.98^{\mathrm{E}}$ & $77.43^{\mathrm{f}}$ & $72.67^{\mathrm{i}}$ & $75.05^{\mathrm{d}}$ & $78.12^{\mathrm{d}}$ & $77.25^{\mathrm{de}}$ & $77.69^{\mathrm{D}}$ \\
NAA 100 ppm & $80.18^{\mathrm{f}}$ & $81.21^{\mathrm{e}}$ & $80.70^{\mathrm{C}}$ & $79.31^{\mathrm{d}}$ & $75.52^{\mathrm{h}}$ & $77.42^{\mathrm{C}}$ & $79.76^{\mathrm{c}}$ & $79.85^{\mathrm{c}}$ & $79.81^{\mathrm{C}}$ \\
SA 200 ppm & $83.39^{\mathrm{b}}$ & $83.87^{\mathrm{a}}$ & $83.63^{\mathrm{A}}$ & $82.44^{\mathrm{a}}$ & $79.87^{\mathrm{c}}$ & $81.16^{\mathrm{A}}$ & $83.60^{\mathrm{a}}$ & $83.22^{\mathrm{a}}$ & $83.41^{\mathrm{A}}$ \\
SA 400 ppm & $81.56^{\mathrm{d}}$ & $82.31^{\mathrm{c}}$ & $81.94^{\mathrm{B}}$ & $80.42^{\mathrm{b}}$ & $77.16^{\mathrm{g}}$ & $78.79^{\mathrm{B}}$ & $81.24^{\mathrm{b}}$ & $81.19^{\mathrm{b}}$ & $81.21^{\mathrm{B}}$ \\
Mean & $79.90^{\mathrm{B}}$ & $81.05^{\mathrm{A}}$ & - & $79.41^{\mathrm{A}}$ & $75.51^{\mathrm{B}}$ & - & $79.89^{\mathrm{A}}$ & $79.65^{\mathrm{A}}$ & - \\
\hline
\end{tabular}

Mean separation within cultivars, treatments and for interaction within each season according to L.S.D. at 0.05 level.

Table 14. Effect of foliar application of Naphthalene acetic acid (NAA) and Salicylic acid (SA) at different concentrations on flesh: stone ratio of Picual and Manzanillo cvs. during 2014, 2015 and 2016 seasons.

\begin{tabular}{|c|c|c|c|c|c|c|c|c|c|}
\hline \multirow{2}{*}{$\begin{array}{l}\text { Cultivars } \\
\text { Treatments }\end{array}$} & \multicolumn{3}{|c|}{2014} & \multicolumn{3}{|c|}{2015} & \multicolumn{3}{|c|}{2016} \\
\hline & Picual & Manzanillo & Mean & Picual & Manzanillo & Mean & Picual & Manzanillo & Mean \\
\hline Control & $3.39^{1}$ & $3.77^{\mathrm{g}}$ & $3.58^{\mathrm{D}}$ & $3.43^{\mathrm{e}}$ & $2.61^{1}$ & $3.02^{\mathrm{E}}$ & $3.29^{\mathrm{n}}$ & $3.30^{\mathrm{h}}$ & $3.30^{\mathrm{E}}$ \\
\hline NAA $50 \mathrm{ppm}$ & $2.28^{\mathrm{J}}$ & $3.72^{\mathrm{h}}$ & $3.00^{\mathrm{E}}$ & $3.43^{\mathrm{e}}$ & $2.66^{\mathrm{h}}$ & $3.05^{\mathrm{D}}$ & $3.57^{\mathrm{t}}$ & $3.40^{\mathrm{g}}$ & $3.49^{\mathrm{D}}$ \\
\hline NAA $100 \mathrm{ppm}$ & $4.04^{1}$ & $4.32^{\mathrm{e}}$ & $4.18^{\mathrm{C}}$ & $3.83^{\mathrm{a}}$ & $3.09^{\mathrm{g}}$ & $3.46^{c}$ & $3.94^{\mathrm{e}}$ & $3.96^{\mathrm{a}}$ & $3.95^{\mathrm{C}}$ \\
\hline SA $200 \mathrm{ppm}$ & $5.02^{\mathrm{b}}$ & $5.20^{\mathrm{a}}$ & $5.11^{\mathrm{A}}$ & $4.69^{\mathrm{a}}$ & $3.97^{\mathrm{c}}$ & $4.33^{\mathrm{A}}$ & $5.10^{\mathrm{a}}$ & $4.96^{\mathrm{b}}$ & $5.03^{\mathrm{A}}$ \\
\hline SA $400 \mathrm{ppm}$ & $4.42^{\mathrm{a}}$ & $4.65^{\mathrm{c}}$ & $4.54^{\mathrm{B}}$ & $4.11^{\mathrm{b}}$ & $3.38^{\mathrm{t}}$ & $3.75^{\mathrm{B}}$ & $4.33^{\mathrm{c}}$ & $4.32^{\mathrm{c}}$ & $4.33^{\mathrm{B}}$ \\
\hline Mean & $3.83^{\mathrm{A}}$ & $4.33^{\mathrm{A}}$ & - & $3.90^{\mathrm{A}}$ & $3.15^{\mathrm{B}}$ & - & $4.05^{\mathrm{A}}$ & $3.99^{\mathrm{A}}$ & - \\
\hline
\end{tabular}

Mean separation within cultivars, treatments and for interaction within each season according to L.S.D. at 0.05 level.

\section{Fruit chemical content:}

Tables (15 and 16) indicated that the moisture percentage and fruit oil percent (in dry weight) of Piual and Manzanillo as the effect of foliar application of Naphthalene acetic acid and Salicylic acid during 2014, 2015 and 2016 seasons.

Concerning the fruit moisture percentage in Table (15) data revealed that the Picual cv. gave the lower significant values during three studied seasons comparing to Manzanillo. Moreover, each of the Salicylic acid treatments at (200 and $400 \mathrm{ppm})$ significantly gave the lowest fruit moisture content. The Salicylic acid treatments at $400 \mathrm{ppm}$ gave lowest moisture content in the first and second seasons. Meanwhile, the Salicylic acid treatment at $200 \mathrm{ppm}$ significantly gave the lowest fruit moisture content in the third season. The control treatment significantly gave the highest fruit moisture content compared to the other treatments in the three seasons.

Table 15. Effect of foliar application of Naphthalene acetic acid (NAA) and Salicylic acid (SA) at different concentrations on fruit moisture content percentage of Picual and Manzanillo cvs. during 2014, 2015 and 2016 seasons.

\begin{tabular}{|c|c|c|c|c|c|c|c|c|c|}
\hline \multirow{2}{*}{$\begin{array}{l}\text { Cultivars } \\
\text { Treatments }\end{array}$} & \multicolumn{3}{|c|}{2014} & \multicolumn{3}{|c|}{2015} & \multicolumn{3}{|c|}{2016} \\
\hline & Picual & Manzanillo & Mean & Picual & Manzanillo & Mean & Picual & Manzanillo & Mean \\
\hline Control & $66.95^{\mathrm{c}}$ & $69.77^{\mathrm{a}}$ & $68.36^{A}$ & $65.64^{\mathrm{e}}$ & $67.75^{\mathrm{a}}$ & $66.69^{\mathrm{A}}$ & $66.52^{b}$ & $68.52^{\mathrm{a}}$ & $67.52^{\mathrm{A}}$ \\
\hline NAA 50 ppm & $66.00^{\mathrm{t}}$ & $67.45^{\mathrm{b}}$ & $66.73^{\mathrm{B}}$ & $64.36^{\mathrm{g}}$ & $66.09^{\mathrm{b}}$ & $65.22^{\mathrm{b}}$ & $65.09^{\mathrm{e}}$ & $66.25^{\mathrm{c}}$ & $65.67^{\mathrm{B}}$ \\
\hline NAA $100 \mathrm{ppm}$ & $64.12^{1}$ & $66.75^{\mathrm{a}}$ & $65.44^{\mathrm{D}}$ & $62.89^{1}$ & $65.89^{\mathrm{c}}$ & $64.39^{\mathrm{C}}$ & $64.00^{\mathrm{t}}$ & $66.09^{\mathrm{a}}$ & $65.04^{c}$ \\
\hline SA $200 \mathrm{ppm}$ & $64.56^{\mathrm{n}}$ & $66.42^{\mathrm{e}}$ & $65.49^{c}$ & $63.19^{n}$ & $65.04^{\mathrm{t}}$ & $64.11^{\mathrm{V}}$ & $63.07^{\mathrm{n}}$ & $65.12^{\mathrm{e}}$ & $64.10^{\mathrm{E}}$ \\
\hline SA 400 ppm & $62.88^{\mathrm{J}}$ & $65.89^{\mathrm{g}}$ & $64.39^{\mathrm{E}}$ & $61.52^{\mathrm{J}}$ & $65.77^{\mathrm{d}}$ & $63.64^{\mathrm{E}}$ & $63.89^{\mathrm{g}}$ & $66.06^{\mathrm{a}}$ & $64.97^{\mathrm{D}}$ \\
\hline Mean & $64.90^{\mathrm{B}}$ & $67.25^{\mathrm{A}}$ & - & $63.52^{\mathrm{B}}$ & $66.11^{\mathrm{A}}$ & . & $64.51^{\mathrm{B}}$ & $66.41^{\mathrm{A}}$ & - \\
\hline
\end{tabular}

Mean separation within cultivars, treatments and for interaction within each season according to L.S.D. at 0.05 level.

In regard to fruit oil percentages (dry weight) as shown in Table (16), it could be noticed that, there were significant differences between the Picual and Manzanillo cvs. in the three seasons. The Picual cv. gave the higher significant values in fruit oil content comparing to Manzanillo cv. and salicylic acid treatments in 200 and 400 ppm gave the highest oil content. The Salicylic acid treatments at 400ppm gave highest oil content in the first and second seasons. Meanwhile, the Salicylic acid treatment at 200 ppm significantly gave the highest fruit oil content in the third season. The control treatment significantly gave the lowest fruit oil content compared to the other treatments in the three seasons.

Table 16. Effect of foliar application of Naphthalene acetic acid (NAA) and Salicylic acid (SA) at different concentrations on fruit oil content percentage of dry weight of Picual and Manzanillo cvs. during 2014, 2015 and 2016 seasons.

\begin{tabular}{lccccccccc}
\hline Cultivars & \multicolumn{3}{c}{$\mathbf{2 0 1 4}$} & \multicolumn{3}{c}{$\mathbf{2 0 1 5}$} & \multicolumn{2}{c}{$\mathbf{2 0 1 6}$} \\
\cline { 2 - 9 } Treatments & Picual & Manzanillo & Mean & Picual & Manzanillo & Mean & Picual & Manzanillo & Mean \\
\hline Control & $33.05^{\mathrm{h}}$ & $30.23^{\mathrm{J}}$ & $31.64^{\mathrm{D}}$ & $34.36^{\mathrm{1}}$ & $32.25^{\mathrm{J}}$ & $33.31^{\mathrm{E}}$ & $33.48^{\mathrm{g}}$ & $31.48^{\mathrm{h}}$ & $32.48^{\mathrm{E}}$ \\
NAA 50 ppm & $34.00^{\mathrm{e}}$ & $32.55^{1}$ & $33.28^{\mathrm{C}}$ & $35.64^{\mathrm{d}}$ & $33.91^{1}$ & $34.77^{\mathrm{D}}$ & $34.91^{\mathrm{d}}$ & $33.75^{\mathrm{t}}$ & $34.33^{\mathrm{D}}$ \\
NAA 100 ppm & $35.88^{\mathrm{b}}$ & $33.25^{\mathrm{g}}$ & $34.56^{\mathrm{B}}$ & $37.11^{\mathrm{b}}$ & $34.11^{\mathrm{h}}$ & $35.61^{\mathrm{C}}$ & $36.00^{\mathrm{C}}$ & $33.91^{\mathrm{e}}$ & $34.95^{\mathrm{C}}$ \\
SA 200 ppm & $35.44^{\mathrm{c}}$ & $33.58^{\mathrm{I}}$ & $34.51^{\mathrm{B}}$ & $36.81^{\mathrm{c}}$ & $34.96^{\mathrm{e}}$ & $35.88^{\mathrm{B}}$ & $36.93^{\mathrm{a}}$ & $34.88^{\mathrm{d}}$ & $35.90^{\mathrm{A}}$ \\
SA 400 ppm & $37.12^{\mathrm{a}}$ & $34.11^{\mathrm{a}}$ & $35.62^{\mathrm{A}}$ & $38.48^{\mathrm{a}}$ & $34.23^{\mathrm{g}}$ & $36.35^{\mathrm{A}}$ & $36.11^{\mathrm{b}}$ & $33.94^{\mathrm{e}}$ & $35.03^{\mathrm{B}}$ \\
Mean & $35.10^{\mathrm{A}}$ & $32.74^{\mathrm{B}}$ & - & $36.48^{\mathrm{A}}$ & $33.89^{\mathrm{B}}$ & - & $35.49^{\mathrm{A}}$ & $33.59^{\mathrm{B}}$ & -
\end{tabular}

Mean separation within cultivars, treatments and for interaction within each season according to L.S.D. at 0.05 level. 
Leaves mineral content:

Table (17) represented that leaves nitrogen content under study significantly differs from the Picual and Manzanillo cvs. in the second and third seasons except in the first season indicated insignificant differences. Picual cv. gave the higher values. Similarly, the salicylic acid treatment at $200 \mathrm{ppm}$ gave the highest nitrogen content in leaves compared to the control and other treatments in the three seasons.

Table 17. Effect of foliar application of Naphthalene acetic acid (NAA) and Salicylic acid (SA) at different concentrations on leaves nitrogen content percentage of Picual and Manzanillo cvs. during 2014, 2015 and 2016 seasons.

\begin{tabular}{lccccccccc}
\hline Cultivars & \multicolumn{3}{c}{$\mathbf{2 0 1 4}$} & \multicolumn{3}{c}{$\mathbf{2 0 1 5}$} & \multicolumn{2}{c}{$\mathbf{2 0 1 6}$} \\
\cline { 2 - 9 } Treatments & Picual & Manzanillo & Mean & Picual & Manzanillo & Mean & Picual & Manzanillo & Mean \\
\hline Control & $1.40^{\mathrm{d}}$ & $1.28^{\mathrm{e}}$ & $1.34^{\mathrm{C}}$ & $1.52^{\mathrm{de}}$ & $1.43^{\mathrm{e}}$ & $1.48^{\mathrm{D}}$ & $1.49^{\mathrm{de}}$ & $1.29^{\mathrm{f}}$ & $1.39^{\mathrm{D}}$ \\
NAA 50 ppm & $1.49^{\mathrm{bcd}}$ & $1.41^{\mathrm{cd}}$ & $1.45^{\mathrm{B}}$ & $1.66^{\mathrm{c}}$ & $1.54^{\mathrm{d}}$ & $1.60^{\mathrm{C}}$ & $1.55^{\mathrm{cde}}$ & $1.44^{\mathrm{e}}$ & $1.50^{\mathrm{C}}$ \\
NAA 100 ppm & $1.52^{\mathrm{b}}$ & $1.49^{\mathrm{bd}}$ & $1.51^{\mathrm{B}}$ & $1.67^{\mathrm{c}}$ & $1.64^{\mathrm{c}}$ & $1.66^{\mathrm{BC}}$ & $1.60^{\mathrm{bcd}}$ & $1.52^{\mathrm{ce}}$ & $1.56^{\mathrm{BC}}$ \\
SA 200 ppm & $1.66^{\mathrm{a}}$ & $1.66^{\mathrm{a}}$ & $1.66^{\mathrm{A}}$ & $1.85^{\mathrm{a}}$ & $1.79^{\mathrm{ab}}$ & $1.82^{\mathrm{A}}$ & $1.78^{\mathrm{a}}$ & $1.70^{\mathrm{ab}}$ & $1.74^{\mathrm{A}}$ \\
SA 400 ppm & $1.50^{\mathrm{bcd}}$ & $1.51^{\mathrm{bc}}$ & $1.51^{\mathrm{B}}$ & $1.71^{\mathrm{bc}}$ & $1.68^{\mathrm{c}}$ & $1.70^{\mathrm{B}}$ & $1.64^{\mathrm{bc}}$ & $1.54^{\mathrm{ce}}$ & $1.59^{\mathrm{B}}$ \\
Mean & $1.51^{\mathrm{A}}$ & $1.47^{\mathrm{A}}$ & - & $1.68^{\mathrm{A}}$ & $1.62^{\mathrm{B}}$ & - & $1.61^{\mathrm{A}}$ & $1.50^{\mathrm{B}}$ & - \\
\hline
\end{tabular}

Mean separation within cultivars, treatments and for interaction within each season according to L.S.D. at 0.05 level.

In regard to the leaves phosphorus content that presented in Table (18), data revealed that, there were significant differences between the Picual and Manzanillo cvs. data appeared that, the Salicylic acid at 200 ppm gave the highest leaves phosphorus content compared to the control and other treatments in the three seasons during three studied seasons. As the effect of treatments on leaves Phosphor content.

Table 18. Effect of foliar application of Naphthalene acetic acid (NAA) and Salicylic acid (SA) at different concentrations on leaves phosphorus content (P\%) of Picual and Manzanillo cvs. during 2014, 2015 and 2016 seasons.

\begin{tabular}{lccccccccc}
\hline Cultivars & \multicolumn{3}{c}{$\mathbf{2 0 1 4}$} & \multicolumn{3}{c}{$\mathbf{2 0 1 5}$} & \multicolumn{2}{c}{$\mathbf{2 0 1 6}$} \\
\cline { 2 - 9 } Treatments & Picual & Manzanillo & Mean & Picual & Manzanillo & Mean & Picual & Manzanillo & Mean \\
\hline Control & $0.24^{\mathrm{c}}$ & $0.26^{\mathrm{bc}}$ & $0.25^{\mathrm{C}}$ & $0.20^{\mathrm{c}}$ & $0.22^{\mathrm{bc}}$ & $0.21^{\mathrm{C}}$ & $0.27^{\mathrm{c}}$ & $0.29^{\mathrm{c}}$ & $0.28^{\mathrm{C}}$ \\
NAA 50 ppm & $0.25^{\mathrm{c}}$ & $0.27^{\mathrm{bc}}$ & $0.26^{\mathrm{C}}$ & $0.21^{\mathrm{bc}}$ & $0.23^{\mathrm{bc}}$ & $0.22^{\mathrm{C}}$ & $0.28^{\mathrm{c}}$ & $0.30^{\mathrm{c}}$ & $0.29^{\mathrm{C}}$ \\
NAA 100 ppm & $0.30^{\mathrm{bc}}$ & $0.33^{\mathrm{b}}$ & $0.32^{\mathrm{B}}$ & $0.26^{\mathrm{bc}}$ & $0.29^{\mathrm{b}}$ & $0.28^{\mathrm{B}}$ & $0.33^{\mathrm{c}}$ & $0.36^{\mathrm{abc}}$ & $0.35^{\mathrm{BC}}$ \\
SA 200 ppm & $0.42^{\mathrm{a}}$ & $0.43^{\mathrm{a}}$ & $0.43^{\mathrm{A}}$ & $0.38^{\mathrm{a}}$ & $0.39^{\mathrm{a}}$ & $0.39^{\mathrm{A}}$ & $0.45^{\mathrm{ab}}$ & $0.46^{\mathrm{a}}$ & $0.46^{\mathrm{A}}$ \\
SA 400 ppm & $0.32^{\mathrm{bc}}$ & $0.41^{\mathrm{a}}$ & $0.37^{\mathrm{B}}$ & $0.28^{\mathrm{bc}}$ & $0.37^{\mathrm{a}}$ & $0.33^{\mathrm{B}}$ & $0.43^{\mathrm{bc}}$ & $0.44^{\mathrm{ab}}$ & $0.40^{\mathrm{AB}}$ \\
Mean & $0.31^{\mathrm{A}}$ & $0.34^{\mathrm{A}}$ & - & $0.27^{\mathrm{A}}$ & $0.30^{\mathrm{A}}$ & - & $0.34^{\mathrm{A}}$ & $0.37^{\mathrm{A}}$ & - \\
\hline
\end{tabular}

Mean separation within cultivars, treatments and for interaction within each season according to L.S.D. at 0.05 level.

As related to the leaves potassium content, results in Table (19) indicated that, there were significant differences between the Picual and Manzanillo cvs. in the second and third seasons, while no significant difference was observed in the first season. Picual cv. gave significantly the higher values The Salicylic acid treatment at $200 \mathrm{ppm}$ significantly gave the highest percentage of leaves potassium content in the three studied seasons compared to the other treatments.

Table 19. Effect of foliar application of Naphthalene acetic acid (NAA) and Salicylic acid (SA) at different concentrations on leaves potassium content (K\%) of Picual and Manzanillo cvs. during 2014, 2015 and 2016 seasons.

\begin{tabular}{lccccccccc}
\hline Cultivars & \multicolumn{3}{c}{$\mathbf{2 0 1 4}$} & \multicolumn{3}{c}{$\mathbf{2 0 1 5}$} & \multicolumn{2}{c}{ 2016 } \\
\cline { 2 - 9 } Treatments & Picual & Manzanillo & Mean & Picual & Manzanillo & Mean & Picual & Manzanillo & Mean \\
\hline Control & $1.11^{\text {de }}$ & $1.07^{\mathrm{e}}$ & $1.09^{\mathrm{E}}$ & $1.02^{\mathrm{de}}$ & $0.98^{\mathrm{e}}$ & $1.00^{\mathrm{E}}$ & $1.24^{\mathrm{ff}}$ & $1.20^{\mathrm{f}}$ & $1.22^{\mathrm{E}}$ \\
NAA 50 ppm & $1.19^{\mathrm{cd}}$ & $1.23^{\mathrm{c}}$ & $1.21^{\mathrm{D}}$ & $1.10^{\mathrm{cd}}$ & $1.14^{\mathrm{c}}$ & $1.12^{\mathrm{D}}$ & $1.32^{\mathrm{de}}$ & $1.36^{\mathrm{cd}}$ & $1.34^{\mathrm{D}}$ \\
NAA 100 ppm & $1.36^{\mathrm{b}}$ & $1.27^{\mathrm{bc}}$ & $1.32^{\mathrm{C}}$ & $1.26^{\mathrm{b}}$ & $1.18^{\mathrm{bc}}$ & $1.22^{\mathrm{C}}$ & $1.45^{\mathrm{bc}}$ & $1.40^{\mathrm{bcd}}$ & $1.43^{\mathrm{C}}$ \\
SA 200 ppm & $1.60^{\mathrm{a}}$ & $1.35^{\mathrm{b}}$ & $1.48^{\mathrm{A}}$ & $1.50^{\mathrm{a}}$ & $1.26^{\mathrm{b}}$ & $1.38^{\mathrm{A}}$ & $1.69^{\mathrm{a}}$ & $1.48^{\mathrm{b}}$ & $1.59^{\mathrm{A}}$ \\
SA 400 ppm & $1.52^{\mathrm{a}}$ & $1.27^{\mathrm{bc}}$ & $1.40^{\mathrm{B}}$ & $1.42^{\mathrm{a}}$ & $1.18^{\mathrm{bc}}$ & $1.30^{\mathrm{B}}$ & $1.61^{\mathrm{a}}$ & $1.40^{\mathrm{bcd}}$ & $1.51^{\mathrm{B}}$ \\
Mean & $1.36^{\mathrm{A}}$ & $1.24^{\mathrm{A}}$ & - & $1.26^{\mathrm{A}}$ & $1.15^{\mathrm{B}}$ & - & $1.46^{\mathrm{A}}$ & $1.37^{\mathrm{B}}$ & -
\end{tabular}

Mean separation within cultivars, treatments and for interaction within each season according to L.S.D. at 0.05 level.

\section{DISCUSSION AND CONCLUSION}

Olive trees is affected by some environmental factors that affect on the flowering process, especially under south Egypt in warm winter conditions the trees must be exposed to a period of winter chilling temperatures (vernalization) in order to emerge inflorescences in the spring which reflect on the productivity (Hassan, 2000)

From the above mentioned results, it was notice that, foliar application of salicylic acid at (200 and 400 ppm) and Naphthalene acetic acid at (50and 100 ppm) improved flowering and fruiting comparing with control. Foliar spray of salicylic acid at $200 \mathrm{ppm}$ at the first week of March before beginning of flowering stage led to improve productivity attributed to increase and the percentage of total perfect flowers in the inflorescence and flowering density. This could be attributed to the role of (SA) as the thermo genesis in plant. (Kalil et al., 2012, Freddey et al., 2007 and Reda et al., 2010). Moreover, it compensates 
insufficient chilling requirements that led to induce flowering and increase density of flowering and percentage of perfect flowers. (Hassan 2000 and Abd El-Razek et al., 2013). The increase in the perfect percentage than other treatments and control due to their role as a growth regulators in the development plant organs. (Hayat et al., 2007). Therefore, the highest yield and fruit physical properties that obtained by (SA) treatment at 200ppm due to the positive effect of antioxidants on fruit physical properties especially fruit weight that reflected on enhanced the yield. (Abd El-Naeem 2000, Maksoud et al., 2009 and Abd El-Rahman and Attia 2016). In addition, their was a positive effect as the spraying treatments for reducing the alternative bearing (Goldschmidt 2005 and Lavee 2007). However, it could be pointed out that the exogenous application of antioxidant had the regulation effect on the essential olive oil percent comparing to control. (Ahmed et al., 2014 and Yousef et al., 2009). As the effect of foliar application of SA on leaves Nitrogen, Phosphor and Potassium, it was more pronounced on the nutrients uptake by the leaves. (Abdel salam 2016 and Hassan 2017).

Finally, foliar spray of salicylic acid at $200 \mathrm{ppm}$ is recommended by application at one month before. beginning of flowering stage for Improving productivity, fruit physical properties and fruit oil content.

\section{REFERENCES}

A.O.A.C. (1990). Association of Official Agricultural, Official Methods of Analysis, 15th ed., Association of Official Analytical Chemists. Washington. D.C., USA.

A.O.A.C. (1995). Association of Official Analytical Chemists Official Methods of Analysis, 15thed. Published by A.O.A.C, Washington, D.C., USA.

Abada, M. A. M. and Abd El- Hameed, H. M (2010). The beneficial effects of spraying salicylic and citric acids on Flame seedless grapevines. The Sixth Inter. of Sustain Agric. And Develop. Fac. of Agric. Fayoum Univ. 27-29 December pp. 153-164.

Abd El-Razek, E., Hassan, H.S. and Gamal El-Din, K. M. (2013). Effect of foliar application with salicylic acid, benzyl-adenine and gibberellic acid on flowering, yield and fruit quality of olive trees (Olea europaea L.). Middle-East J. Sci. Res., 14: 14011406.

Abd El-Naeem, B. A. (2000). Studies on flowering and fruit set of some olive cultivars under Assiut environments. Ph. D. Thesis, Fac. Agric., Assiut Univ.

Abd-El-Rhman, I. E. and Attia, M. F. (2016). Foliar spray with potassium nitrate and salicylic acid for improving growth, yield and nutrients uptake by olive trees under salinity stress conditions. /International Journal of Chem. Tech. Research, 9: $230-245$.

Abdel-Salam, M. M. (2016). Effect of Foliar Application of Salicylic Acid and Micronutrients on the Berries Quality of "Bez El Naka" Local Grape Cultivar. Middle East J. Appl. Sci. 6: 178 - 188.
Agusti, M. J., Almela, V. and Gariglio, N. (2000). Loquat fruit size is increased through the thinning effect of naphthalene acetic acid. Plant Growth Regul. 31: 167-171.

Ahmed, F. F., Ibrahim, H. I. M., Abada, M. A. M. and Osman, M. M. M. (2014). Using plant extracts and chemical rest breakages for breaking bud dormancy and improving productivity of Superior grapevines growing under hot climates. World Rural Observations, 6: 8-18.

Brown, J. D. and Lilleland, D. (1946). Rapid determination of potassium and sodium in plant material and soil extract by flame photometer. Proc. Amer. Soc. Hort. Sci. 48 ,P :341

Dimitrios, P.N., I.C. Tzanetos, P.N. Georgia and P. Nikos( 2008). A portable sensor for the rapid detection of naphthalene acetic acid in fruits and vegetables using stabilized in air lipid films with incorporated auxinbinding protein 1 receptor. Talanta, 77: 786- 792.

Duncan,B. D.(1955). Multiple test range and multiple F tests. -Biometries, 11142

Fouad, M. M., Kilany, O. A. and El-Said, M. E. (1992). Comparative studies on flowering, fruit set and yield of some olive cultivars under Giza condition. Egypt. J. Appl. Sci. 7:360-644.

Freddey, M., Franisco, Franisco, T., Carlos, S. and Elias, M. (2007). Vegetative growth and early production of six olive cultivars, in Southern Atacoma desert, Chile. Journal of central European Agriculture, 8(3): 269-279.

Goldschmidt, E. (2005). Regulatory aspects of alternate bearing in fruit trees. Italus-Hortus, 12: 11-17.

Hassan, S.A.H. (2000). Studies on morphological and physiological on flowering; pollination and fruiting of picual olive trees. Ph.D. Thesis, Fac. of Agric., Cairo Univ., Egypt.

Hassan, S. G. (2017). Effect of foliar spraying solution Grow green and Salicylic acid in growth of sour orange trees(Citrus aurantium L.) Karbala J. of Agric. Sci., 4: 112 - 123.

Hayat, S., Irfan, M. and Ahmad, A. (2010). Effect of exogenous salicylic acid under changing environment: A review. Environ. Exp. Bot., 681, 1425.

Hayat, S., Ali, B. and Ahmad, A. (2007). Salicylic acid: biosynthesis, metabolism and physiological role in plants. Salicylic Acid - A Plant Hormone, 1-14.

Khalil, F., Qureshi, K. M., Khan, A., Hassan, F. and Bibi, N. (2012). Effect of girdling and plant growth regulators on productivity in olive (Olea europaea). Pakistan J. Agric. Res., 25: 120 - 128.

Khankahdani, H. H., Bahrami, H. R. and Aboutalebi, A. (2013). Examination the possibility of bearing regulation of Siahoo mandarin (Citrus reticulata Blanco) by using chemical thinning components. Intl. Res. J. Appl. Basic. Sci. 4 (2): 311 - 315.

Krueger, W. H., Maranto, J. and Sibbett, G. S. (2004). Olive fruit thinning. In: Olive Production Manual. Sibbett, G.S. and Ferguson, L. (Eds.) Pp. 101-104. University of California, Agriculture and Natural Resources Publication 3353, Oakland, California, USA. 


\section{J. Plant Production, Mansoura Univ., Vol. 9 (10), October, 2018}

Lavee, S. (2007). Biennial bearing in olive (Olea europaea L.). Annals Ser. Hist. Nat, 17: 101-112.

Mahdi, J., Kambiz, M., Dadkhan, A. and Tavallaee, F. Z. (2012). Effects of Salicylic acid on-yield and quality character of tomato fruit (Lycopersiconesculentum Mill.)International Journal of Agriculture and Crop Science (14-16): 1184-87.

Maksoud, M. A., Saleh, M. A., El-Shamma, M. S. and Fouad, A. A. (2009). The beneficial effect of biofertilizers and antioxidants on olive trees under calcareous soil conditions. World J. Agric. Sci., 5: $350-352$.

Murphy, J. and Riely, J.P. (1962). A modified single dilution method for determination of phosphate in natural water. Ann. Chemi. Acta, 27:P: 31-36.

Pregl, F. (1945). Quantitative organic micro-analysis. $4^{\text {th }}$ Ed, and A. Churchill. LTD. London. PP:126-129.

Raskin, I. (1992). Role of salicylic acid in plants. Ann. Rev. Plant Physiol. and Plant Mol. Biol., 43: 439463.
Reda, F., AbdEl-Wahed, M.S.A. and Gamal El-Din, K.M. (2010). Effect of indole acetic acid, gibberellic acid and kinetin on vegetative growth, flowering, essential oil pattern of Chamomile plant (Chamomilla-recutita L. Rausch). World J. Agric. Sci., 6: 595-600.

Snedecor, G. W. and Cochran, W. G. (1972). Statistical Methods. $7^{\text {th }}$ Ed. The Iowa State Univ., Press Ames, Iowa, U.S.A., pp 593.

Wassel, A.M.M., Ahmed, F.F., El-Mamlouk, E.A.H. and Fekry, W.M.E. (2011). Relieving clusters looseness and shot berries in Red Roomy grapevines by using some antioxidants. Minia J. of Agric. Res J. develop. 31: 205 - 217.

Wilcox, J.C. (1944). Some factors affecting apple yield in the Okanagan Valley. Sci., Agric., 25: 97-104.

Yousef, A.R.M., Ayad, H.S. and Saleh, M.M.S. (2009). The beneficial effect of spraying some antioxidant vitamins on fruit quality, oil composition and improving-oil characteristics of Picaul olive. World J. Agric. Sci., 5: 871- 880 .

\footnotetext{
تأثير الرش الورقي ببعض منظمات النمو التباتية على نمو وإنتاجية أشجار الزيتون تحت ظروف جنوب مصر

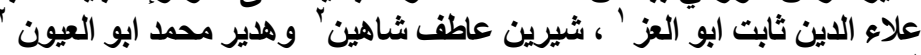

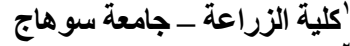
'معهد بحوث البساتين - الجيزة

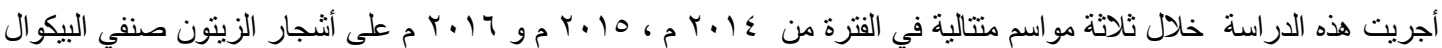

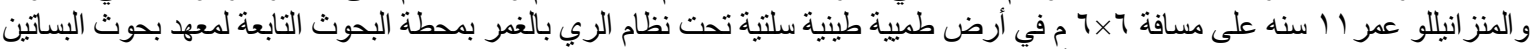

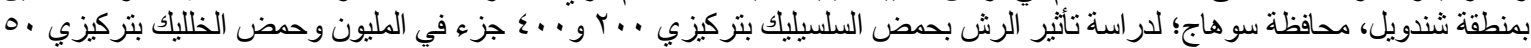

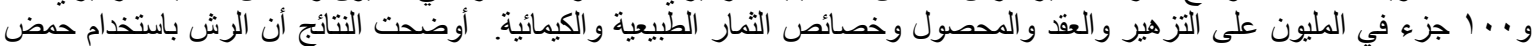

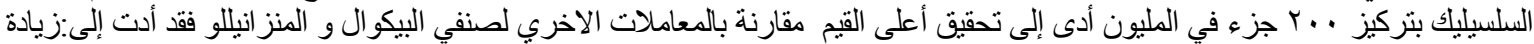

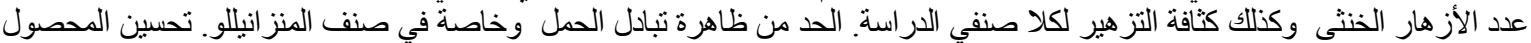

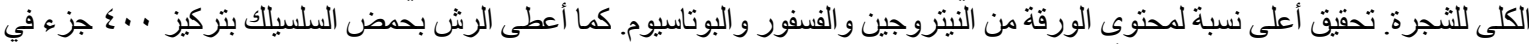

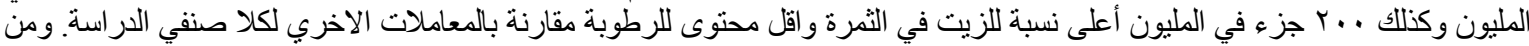

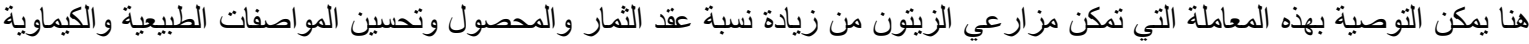

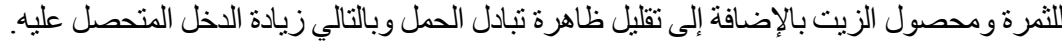

